\title{
Spatial variation in the structure and composition of the herbaceous community in a semiarid region of northeastern Brazil
}

\author{
Silva, KA. ${ }^{a, b *}$, Santos, JMFF. ${ }^{b}$ Santos, DM. ${ }^{b}$, Ferraz EMN. ${ }^{c}$ and Araújo EL. ${ }^{b}$ \\ a'Laboratório de Biodiversidade, Centro Acadêmico de Vitória, Universidade Federal de Pernambuco - UFPE, \\ Alto do Reservatório, CEP 55608-680, Vitória de Santo Antão, PE, Brazil \\ bLaboratório de Ecologia Vegetal dos Ecossistemas Naturais - LEVEN, Departamento de Biologia, Área de Botânica, \\ Universidade Federal Rural de Pernambuco - UFRPE, Dois Irmãos, CEP 52171-900, Recife, PE, Brazil \\ 'Instituto Federal de Educação, Ciência e Tecnologia de Pernambuco - IFPE, \\ Cidade Universitária, CEP 50740-540, Recife, PE, Brazil \\ *e-mail: kleberandradedasilva@hotmail.com
}

Received February 2, 2012 - Accepted April 25, 2012 - February 28, 2013

(With 1 figure)

\begin{abstract}
In the arid and semiarid environments of the world, microhabitats serve as models for the structure of vegetation communities. The goal of this study was to identify differences in the structures of the herbaceous communities growing on a crystalline substrate and those growing on a sedimentary substrate in a semiarid region of northeastern Brazil. One hundred $1 \times 1 \mathrm{~m}$ plots were established in each area for quantitative sampling, with 69 species recorded in the crystalline area and 76 in the sedimentary area. The average plant density was higher in the sedimentary area, and average diameters and heights were greater in the crystalline area. The families and species with a high Importance Value Index (IVI) and a high Mixed Ecological Value Index (MEVI) differed between the areas. Of the species with high densities, only four were found in both areas. Shannon-Weiner diversity index values in the crystalline $\left(2.96\right.$ nats/ind..$\left.^{-1}\right)$ and sedimentary (2.89 nats/ind..$\left.^{-1}\right)$ areas were similar. Evenness values on both substrates were also similar $(0.72$ and 0.71 in the crystalline and sedimentary areas, respectively). This study shows that variations in plant establishment conditions between crystalline and sedimentary areas in a semiarid region of northeastern Brazil should be considered as structure-modeling factors for the herbaceous community.
\end{abstract}

Keywords: dry forest, phytosociology, herb, soil, caatinga, microhabitat.

\section{Variação espacial na estrutura da comunidade herbácea em uma região semiárida do Nordeste do Brasil}

\section{Resumo}

Nos ambientes áridos e semiáridos do mundo, os micro-habitats modelam a estrutura das comunidades vegetais. $\mathrm{O}$ objetivo deste estudo foi identificar diferenças nas estruturas das comunidades herbáceas instaladas sobre o solo do embasamento cristalino e a bacia sedimentar em uma região semiárida do Nordeste do Brasil. Foram estabelecidas 100 parcelas de $1 \times 1 \mathrm{~m}$ em cada área para amostragem das comunidades. Foram registradas 69 espécies na área cristalina e 76 na área sedimentar. A densidade média das plantas foi maior na área sedimentar e os diâmetros e as alturas médias foram maiores na área cristalina. As famílias e as espécies com maior Índice de Valor de Importância (IVI) e Índice de Valor Ecológico Mixto (IVEM) diferiram entre as áreas. Das espécies com maior densidade, apenas quatro foram encontradas em ambas as áreas. Os valores dos índices de diversidade Shannon-Weiner das áreas do cristalino (2,96 nats/ind..$\left.^{-1}\right)$ e sedimentar $\left(2,89\right.$ nats/ind. $\left.{ }^{-1}\right)$ foram semelhantes. Os valores de equabilidade, em ambas as áreas, também foram semelhantes ( 0,72 e 0,71, nas áreas cristalina e sedimentar, respectivamente). Este estudo mostra que as variações nas condições de estabelecimento das plantas entre áreas cristalinas e sedimentares, em uma região semiárida do Nordeste do Brasil, devem ser consideradas como um fator modelador da estrutura das comunidades herbáceas.

Palavras-chave: floresta seca, fitossociologia, erva, solo, caatinga, micro-habitat. 


\section{Introduction}

Spatial variations in floristic composition and in the structure of vegetable communities have been characterised in a number of arid and semiarid regions in the world, contributing to the growing body of knowledge on the biodiversity of plants in these environments (Albuquerque et al., 2005; Fulbright, 2004; He et al., 2007; Morgenthal et al., 2006; Ramírez et al., 2007; Rodal and Nascimento, 2006; Silva et al., 2009).

According to the literature, variations in plant establishment conditions (microhabitats) may favour increased species richness and changes in community composition and structure on a small spatial scale. For example, (1) microhabitats can have specific microclimatic and edaphic characteristics that allow the establishment of particular species, including rare species, and reduce the densities of generalist populations from nearby microhabitats (Alcoforado-Filho et al., 2003; Araújo et al., 2005; Fulbright, 2004; Lemos and Rodal, 2002; Reis et al., 2006; Silva et al., 2009); (2) variations in soil texture and the availability of nutrients help determine the species composition and vegetation types (Aarrestad et al., 2011; Amorim and Batalha, 2008; Araújo et al., 1999; Cañadas et al., 2010; He et al., 2007; Morgenthal et al., 2006; Ramírez et al., 2007); (3) soils with a higher water retention capacity allow increased biomass and ground cover (Alhamad et al., 2010; Munhoz et al., 2008); (4) the composition and structure of herbaceous plant communities growing under the canopy of woody species may be distinct from those in open areas due to litter fall, light interception and changes in nutrient availability (Cabin and Marshall, 2000; Fuller, 1999). Consequently, the vegetation community structure may be very different even among microhabitats in close proximity.

In Brazil, the semiarid environment is largely occupied by caatinga vegetation (Andrade-Lima, 1981) and is characterised by a clear distinction of climatic seasons, with a rainy season (lasting from three to six months) and a dry season (lasting from six to nine months). The annual precipitation varies from 252 to $1200 \mathrm{~mm}$, and the rainy season accounts for 80 to $90 \%$ of the total annual rainfall with irregular distribution (Araújo et al., 2007; Sampaio, 1995). In the caatinga, there are broad areas with vegetation established in soils with an underlying crystalline basement and areas established in sedimentary basins. These areas constitute two distinct microhabitat conditions because soils from crystalline regions are generally shallower and rockier with medium to high fertility, whereas soils from sedimentary areas are much deeper and sandier with medium to low fertility (Brasil, 1983; Jacomine et al., 1973; Sampaio and Gamarra-Rojas, 2003; Silva et al., 2009). Thus, these areas represent an ideal opportunity to investigate the influence of crystalline basement soils versus soils from sedimentary basins on the structure of the herbaceous component in the caatinga.

Therefore, based on the premise that there is a relationship between plant establishment conditions and the structure and composition of vegetation communities in arid and semiarid environments around the world, the hypothesis this study is that variations in the physiochemical characteristics of the soil can be expected to affect the structure and composition of the herbaceous component in the caatinga. The goal of this study was to phytosociologically characterise the herbaceous component of caatinga vegetation communities growing in crystalline and sedimentary soils and to identify differences in community structure in these areas.

\section{Material and Methods}

\subsection{Study area}

The study was conducted in two caatinga communities in the municipality of Petrolândia, Pernambuco, in the District of Mundo Novo. One area was established on sandy soils in a region of basins and sedimentary coverage ( $9^{\circ} 04^{\prime} 57^{\prime \prime} \mathrm{S}$ and $38^{\circ} 13^{\prime} 47^{\prime \prime} \mathrm{W}$, at an elevation of $432 \mathrm{~m}$ ) and the other on rocky soils underlain by an exposed crystalline shield $\left(9^{\circ} 05^{\prime} 27^{\prime \prime} \mathrm{S}\right.$ and $38^{\circ} 13^{\prime} 43^{\prime}$ ' W, at an elevation of $430 \mathrm{~m}$ ) in accordance with classification of Brazil (1983); these areas are henceforth referred to as sedimentary and crystalline areas, respectively. Both areas are drained by the Salgado Stream, which originates on the Serra do Tacaratu and flows into the São Francisco River (FIAM/DI, 1986), and both areas have a local climate typical of the hot, semiarid Bshw classification, with concentrated rains from January to May and an annual rainfall of approximately $435 \mathrm{~mm}$. The average temperature remains close to $25^{\circ} \mathrm{C}$ year round, with $55 \%$ relative humidity and an average annual evaporation of 3,008 mm/year (Brasil, 1983; FIAM/DI, 1986; Perazzo, 2002). The areas are close to each other (approximately $1.5 \mathrm{~km}$ ) and on private property; the landowners reported that the areas selected for this study had not been subject to agricultural or extensive livestock influences for at least 20 years. Because the herbaceous flora of the caatinga is sensitive to variations in rainfall (Araújo et al., 2002, 2007; Reis et al., 2006), care was taken to select sampling areas that were close together, with the aim of decreasing the influence of local climatic variations on community structure.

The soils of the crystalline area had average values of $83.1 \%, 9.4 \%$ and $7.5 \%$ for sand, clay and silt content, respectively; $12.16 \%$ field capacity; water $\mathrm{pH}$ of 6.0 ; exchangeable $\mathrm{K}, \mathrm{Ca}, \mathrm{Mg}, \mathrm{H}$ and $\mathrm{Al}$ contents of $0.23,3.7$, $2.3,1.35$ and $0.05 \mathrm{cmol} / \mathrm{dm}$, respectively; $96 \mathrm{mg} / \mathrm{dm}$ of available P and $10.07 \mathrm{~g} / \mathrm{kg}$ of carbon. Soils of the sedimentary area had average values of $89.9 \%, 4.6 \%$ and $5.5 \%$ for sand, clay and silt content, respectively; $8.36 \%$ field capacity; water $\mathrm{pH}$ of 5.6 ; exchangeable $\mathrm{K}, \mathrm{Ca}, \mathrm{Mg}, \mathrm{H}$ and $\mathrm{Al}$ contents of 0.05, 2.3, 1.1, 0.6 and $0.1 \mathrm{cmol} / \mathrm{dm} ; 4.7 \mathrm{mg} / \mathrm{dm}$ of available $\mathrm{P}$ and $4.13 \mathrm{~g} / \mathrm{kg}$ of carbon (Silva et al., 2009).

In the crystalline area, the tree species showed superposition of crowns, forming an almost continuous canopy and allowing very little light to penetrate. The area included rocky outcrops where Bromeliaceae species, mainly Encholirium spectabile, and species of Cactaceae were 
established and influenced the physiognomy of the area. Prominent woody species present in the crystalline area included Caesalpinia pyramidalis Tul., Capparis flexuosa (L.) L., Commiphora leptophoeos (Mart.) J.B. Gillett, Croton argyrophylloides Müll. Arg., Guettarda angelica Mart. ex Müll. Arg., Myracrodruon urundeuva Allemão, Opuntia palmadora Mill, Pilosocereus gounellei (F.A.C. Weber) Byles \& G.D. Rowley, Rhamnidium elaeocarpum Reissek, Syderoxyllum obtusifolium (Roem. \& Schult.) T.D. Penn., Syagrus coronata (Mart.) Becc. and Ziziphus joazeiro Mart.. C. argyrophylloides was especially abundant and influential in the local physiognomy (Silva et al., 2009).

In the sedimentary area, there was practically no superposition of the crowns of woody plants, which resulted in a discontinuous canopy (forming islands of vegetation surrounded by land without woody vegetation) and places with greater penetration of sunlight than in the crystalline area. In these places, Jatropha mollissima (Pohl) Baill. and J. ribifolia (Pohl) Baill. were most abundant. In general, the woody flora of the sedimentary area was characterised by the presence of species such as Amburana cearensis (Allemão) A.C. Sm, Anadenanthera macrocarpa (Benth.) Brenan, Aspidosperma pyrifolium Mart., Bauhinia cheilantha (Bong.) Steud., Cereus jamacaru DC., Caesalpinia microphylla Buch.-Ham., Cnidoscolus phyllacanthus (Müll. Arg.) Pax \& L. Hoffm., Commiphora leptophloeos (Mart.) J.B. Gillett, Croton rhamnifolioides Pax \& K. Hoffm, Guettarda angelica Mart. ex Müll. Arg., Lantana camara L., Maytenus rigida Mart., Opuntia palmadora Mill, Spondias tuberosa Arruda, Rhamnidium elaeocarpum Reissek, Rolliniopsis leptopetala (R.E. Fr.) Saff., Ziziphus joazeiro Mart. and species of Myrtaceae and Rutaceae (Silva et al., 2009).

\subsection{Herbaceous sampling}

One hundred $1 \mathrm{x} 1 \mathrm{~m}$ plots were established in the crystalline area and one hundred plots in the sedimentary area. In both areas, 10 transects perpendicular to and beginning $5 \mathrm{~m}$ from the forest border were installed $10 \mathrm{~m}$ apart. Along each transect, 10 plots were established at a fixed distance of $5 \mathrm{~m}$.

Ground-layer herbaceous showed differences in their degrees of lignification and in the visibility of their stalks at soil level; they were considered herbaceous if 1) all individuals had non-lignified stalks or stalks with a low level of lignification and color ranging from green to brownish, with or without a trailing habit or 2) the plants that at ground level had aerial system directly represented by the leaves. In the latter cases, the stalks of the herbs were not typically visible above soil level, but when they were visible they were small, decumbent and rhizomatous. Such a growth habit was recorded only for species of Bromeliaceae and Amaryllidaceae.

In the plot interiors, all herbaceous individuals were counted, marked and measured for stalk height and diameter at soil level. Height was measured with a ruler or measuring tape, and diameter was measured with a digital caliper. All plants unattached to one another at soil level were considered as individuals. For individuals branched at soil level (tillers) without a visible common stalk base, the total diameter of the individual was calculated based on the diameters of all tillers present. For individuals without a visible stalk at soil level but with a leaf (ex. Hipeastrum sp. - Amaryllidaceae) or a rosette formed by a group of leaves (ex. Encholirium spectabile - Bromeliaceae), the bases of the leaves or rosettes were measured. The height of a plant was measured from soil level, regardless of whether the plant had a stalk and leaves or only leaves at that point.

The reproductive parts of all flowering herbaceous species in the interior of or near the plots were collected for taxonomic identification. Monthly trips were made to the study areas to collect the flowering parts of species that had been in the vegetative stage during previous samplings and to monitor the persistence of the aboveground parts of herbaceous plants. These data were used in calculations of the mixed ecological value index (MEVI) proposed by Feitoza et al. (2008). In addition to the phytosociological parameters that are part of the importance value index (IVI), MEVI takes into account the number of months that a species is visible in the community.

Because of morphological characteristics exhibited by some species early in their ontogeny, some young herbaceous plants were mistaken as seedlings of woody species. To correct this mistake, individuals of these species were collected, planted in polyethylene containers with soil from the site, transported to the greenhouse at the Universidade Federal Rural de Pernambuco and monitored for six months until reproductive material could be obtained for correct taxonomic identification of the species. A period of six months was established because this was a longer duration than that of the local rainy season, a period during which most herbs complete their life cycles in the caatinga vegetation (Araújo et al., 2002).

\subsection{Treatment and data analysis}

Plant material was herborised following the usual techniques for preparing, drying and assembling exsiccates (Mori et al., 1989). Taxonomic identification was accomplished by comparisons with exsiccates deposited in the herbaria Professor Vasconcelos Sobrinho - PEUFR and Dárdano de Andrade Lima - IPA and with the help of taxonomic keys and specific literature in accordance with the Cronquist classification system (1988). The classification system chosen was not the APG, because it is a classification system subject to change. Exsiccates of species with problematic or dubious identification were sent to experts. The spelling of the name of each species was checked by referring to the Index Kewensis (www. ipni.org/ipni/plantnamesearchpage.do) and the database of the Missouri Botanical Garden's VAST - MOBOT (www. mobot.mobot.org/W3T/Search/vast.html). Abbreviations of the names of species' authors followed either Brummitt and Powell (1992) or the MOBOT. After identification, the exsiccates collected by K.A. Silva were incorporated into the herbarium of Professor Vasconcelos Sobrinho - PEUFR, 
and duplicates were sent to the herbarium of Dárdano de Andrade Lima - IPA.

The Shannon-Wiener diversity index (H'), the evenness and the following phytosociological parameters were calculated: absolute density (AD), absolute dominance (ADo), absolute frequency (AF) and importance value index (IVI). All parameters were calculated using the FITOPAC program (Shepherd, 1995). The MEVI was calculated with the following formula: $\mathrm{MEVI}=\mathrm{APP}+\mathrm{IVI}_{\mathrm{f}}$, where APP (Apparent Physiognomic Permanence) is the number of months that a species kept its leaves or was visible in the habitat divided by the number of months in a year, and the IVI $_{\mathrm{f}}$ (fraction of the IVI value) is the IVI of the species divided by the total IVI. The differences in average densities, heights and diameters between the sedimentary and crystalline areas were checked by the Kruskal-Wallis variance test (Zar, 1996).

A quantitative matrix was developed that was composed of the number of individuals from the 77 species and the 200 plots in both the sedimentary and crystalline areas. From this matrix, the degree of difference in structure between crystalline and sedimentary areas was evaluated through group analysis using the Bray-Curtis distance index and the unweighted pair group method with the arithmetic mean (UPGMA). The analysis was done using the PC ORD4 System (McCune and Mefford, 1999). The causality of group linkage analysis was evaluated with a Monte Carlo procedure with a $5 \%$ probability criterion using the RandMat 1.0 program (http://eco.ib.usp.br/labmar).

\section{Results}

\subsection{Species richness and composition}

The total herbaceous flora of crystalline and sedimentary areas consisted of 39 families, 75 genera and 95 species, of which 77 were present in the sampled area of $200 \mathrm{~m}^{2}$ (Tables 1 and 2). The flora of the crystalline area contained 69 species, of which 62 were present in the $100 \mathrm{~m}^{2}$ sampling area; the flora of the sedimentary area contained 78 species, of which, 59 were present in the $100 \mathrm{~m}^{2}$ sampling area. These values show that more than $75 \%$ of the herbaceous flora of the areas was found in the sampled areas, and the sampling was therefore considered adequate. Fifty-two species were common to both areas. Seventeen species occurred only in the crystalline and 26 species occurred only in the sedimentary area.

\subsection{Structure}

The total density in the sedimentary and crystalline areas was 16,133 individuals $/ 100 \mathrm{~m}^{2}$ and 9.525 individuals $/ 100 \mathrm{~m}^{2}$ respectively. The average density (individuals $/ \mathrm{m}^{2}$ ) was significantly higher in the sedimentary area $(161.33 \pm 80.12)$ than in the crystalline area $(95.25 \pm 65.73)$, according to the Kruskal-Wallis variance test $(H=34.0188 ; \mathrm{p}<0.0001)$. The density values in this study provide a total density estimate of 1,613,300 individuals/ha in the sedimentary area and 952,500 individuals/ha in the crystalline area.
The total basal areas were $85.86 \mathrm{~m}^{2} /$ ha and $28.16 \mathrm{~m}^{2} / \mathrm{ha}$ in the crystalline and sedimentary areas, respectively. The average diameter $(\mathrm{cm})$ of herbaceous plants was significantly higher in the crystalline area $(1.16 \pm 2.56)$ than in the sedimentary area $(0.14 \pm 0.17)$, according to the KruskalWallis variance test $(H=4.9115 ; \mathrm{p}=0.0267)$. The average height $(\mathrm{cm})$ of plants in the herbaceous community was significantly higher in the crystalline area $(25.32 \pm 39.02)$ than in the sedimentary area $(4.86 \pm 2.02)$, according to the Kruskal-Wallis variance test $(H=96.4709 ; \mathrm{p}<0.0001)$.

The families with the highest importance values differed between the sedimentary and crystalline areas (Tables 1 and 2). In the crystalline area, the families with the highest IVI values included Bromeliaceae, Cactaceae, Commelinaceae, Phytolaccaceae and Euphorbiaceae, with a total of $56.57 \%$ of the total IVI (Table 1). In the sedimentary area, the families with the highest IVI values were Cactaceae, Rubiaceae, Convolvulaceae, Poaceae and Molluginaceae, with a total of $62.3 \%$ of the total IVI (Table 2).

The species with highest ecological importance in the crystalline area were Encholirium spectabile, Hohenbergia catingae, Callisia repens, Opuntia inamoena and Microtea paniculata, accounting for $45.2 \%$ of the total IVI (Table 1). In contrast, the species with the highest MEVI were Melocactus bahiensis, Neoglaziovia variegata, Herissantia tiubae, Ipomoea brasiliana, Pseudomalacra guianensis and Cardiospermum sp. (Table 1).

In the sedimentary area, the species with the highest IVI were Opuntia inamoena, Staelia virgata, Richardia grandiflora, Mollugo verticilata and Evolvulus frankenioides, accounting for $54.2 \%$ of total IVI (Table 2). The species with the highest MEVI were Herissantia tiubae, Eragrostis ciliaris, Pseudomalacra guianensis, Zornia brasiliensis, Cardiospermum sp. and Ayenia erecta (Table 2).

Overall, the species with the highest density in the crystalline area were Callisia repens, Microtea paniculata, Mollugo verticilata, Panicum trichoides, Phyllanthus niruri, Alternanthera tenela, Richardia grandiflora, Herissantia tiubae and Cleome diffusa, accounting for $74.6 \%$ of the total density (Table 1). In the sedimentary area, the species with the highest densities were Staelia virgata, Richardia grandiflora, Mollugo verticilata, Evolvulus frankenioides, Phyllanthus niruri, Portulaca elatior, Hyptis atrorubens and Panicum trichoides, which together accounted for $71.3 \%$ of the total density (Table 2 ).

The values obtained for the Shannon-Weiner diversity index in the crystalline and sedimentary areas were 2.96 and 2.89 nats/ind., respectively. The distribution of the number of individuals by species was similar between the crystalline and sedimentary areas, with evenness values of 0.72 and 0.71 , respectively. The group analysis results showed a trend of separation in the structural characteristics of the herbaceous communities of the crystalline and sedimentary areas and that even within an area, the density is not homogeneous; in both the crystalline and sedimentary areas, two structural groups were observed (Figure 1). 
Table 1. Phytosociological characterisation of a caatinga herbaceous community in a crystalline basement area, Petrolândia, Pernambuco, Brazil, with families ranked by decreasing values of the importance value index.

\begin{tabular}{|c|c|c|c|c|c|c|}
\hline Family/species & $\begin{array}{l}\text { Registry } \\
\text { number }\end{array}$ & AD & ADo & $\mathbf{A F}$ & IVI & MEVI \\
\hline Bromeliaceae & & 16900 & 63.0552 & 24 & 25.97 & \\
\hline Encholirium spectabile Mart. ex Schult.f & 45411 & 3400 & 36.626 & 11 & 44.07 & 1.146 \\
\hline Hohenbergia catingae Ule & 45412 & 4900 & 23.6005 & 7 & 28.6 & 1.095 \\
\hline Neoglaziovia variegata $\mathrm{Mez}$ & 45413 & 8600 & 2.8287 & 6 & 4.77 & 1.015 \\
\hline Cactaceae & & 7800 & 20.7888 & 13 & 8.83 & \\
\hline Opuntia inamoena K. Schum. & 45414 & 7500 & 15.7716 & 10 & 20.12 & 1.067 \\
\hline Melocactus bahiensis (Britton \& Rose.) Werderm. & 45482 & 300 & 5.0172 & 3 & 6.16 & 1.020 \\
\hline Commelinaceae & & 168900 & 0.2208 & 62 & 8.33 & \\
\hline Callisia repens $\mathrm{L}$. & 45421 & 165200 & 0.1731 & 55 & 22.84 & 0.409 \\
\hline Commelina obliqua Vahl & 45423 & 3700 & 0.0477 & 20 & 2.37 & 0.591 \\
\hline Phytolacaceae & & 116600 & 0.4475 & 74 & 7.04 & \\
\hline Microtea paniculata Moq. & 45461 & 116600 & 0.4475 & 74 & 19.88 & 0.399 \\
\hline Euphorbiaceae & & 102800 & 0.0428 & 74 & 6.4 & \\
\hline Phyllanthus niruri L. & 45641 & 68200 & 0.0127 & 50 & 11.99 & 0.289 \\
\hline Acalypha poiretii Spreng. & 45438 & 26100 & 0.0213 & 30 & 5.65 & 0.352 \\
\hline Croton lobatus (L.) Müll. Arg. & 45443 & 3800 & 0.0045 & 15 & 1.85 & 0.339 \\
\hline \multicolumn{7}{|l|}{ Euphorbiaceae } \\
\hline Bernardia sidoides (Klotzsch) Müll. Arg. & 45440 & 1700 & 0.0015 & 11 & 1.24 & 0.337 \\
\hline Dalechampia scandens L. & 45444 & 1800 & 0.0020 & 9 & 1.06 & 0.670 \\
\hline Phyllanthus heteradenius Müll. Arg. & 45445 & 1100 & 0.0008 & 7 & 0.79 & 0.335 \\
\hline Chamaesyce hyssopifolia (L.) Small & 45441 & 100 & 0.0001 & 1 & 0.11 & 0.500 \\
\hline Poaceae & & 93500 & 0.2236 & 73 & 6.11 & \\
\hline Panicum trichoides Sw. & 45644 & 76000 & 0.0904 & 64 & 14.24 & 0.380 \\
\hline Eragrostis ciliaris (L.) R. Br. & 45457 & 9500 & 0.0137 & 18 & 2.75 & 0.509 \\
\hline Enteropogon mollis (Nees) Clayton & 45646 & 3600 & 0.0858 & 4 & 0.86 & 0.419 \\
\hline Digitaria sanguinalis (L.) Scop. & 45459 & 900 & 0.0030 & 7 & 0.77 & 0.419 \\
\hline Axonopus capillaris (Lam.) Chase & 45844 & 2500 & 0.0281 & 4 & 0.68 & 0.335 \\
\hline Dactyloctenium aegyptium (L.) K.Richt & 45460 & 700 & 0.0009 & 3 & 0.36 & 0.251 \\
\hline Tragus berteronianus Schult. & 45454 & 300 & 0.0016 & 1 & 0.13 & 0.750 \\
\hline Eragrostis amabilis (L.) Wight \& Arn. & 45645 & * & & & & \\
\hline Eragrostis tenella (L.) Roem. \& Schult. & 45456 & $*$ & & & & \\
\hline Molluginaceae & & 97200 & 0.2229 & 56 & 5.6 & \\
\hline Mollugo verticillata $\mathrm{L}$. & 45637 & 97200 & 0.2229 & 56 & 15.85 & 0.386 \\
\hline Rubiaceae & & 72900 & 0.0556 & 51 & 4.49 & \\
\hline Richardia grandiflora (Cham. \& Schltdl.) Steud. & 45848 & 48500 & 0.0484 & 31 & 8.13 & 0.360 \\
\hline Staelia virgata (R \& S.) K.Schum. & 45846 & 16700 & 0.0037 & 23 & 3.97 & 0.346 \\
\hline Mitracarpus scabrellus Benth. & 47684 & 7700 & 0.0034 & 10 & 1.77 & 0.422 \\
\hline Malvaceae & & 52700 & 0.0625 & 66 & 4.35 & \\
\hline Herissantia tiubae (K. Schum.) Brizicky & 45666 & 44000 & 0.0340 & 50 & 9.47 & 0.781 \\
\hline Pseudomalacra guianensis (K. Schum.) H.Monteiro & 45665 & 5800 & 0.0174 & 22 & 2.75 & 0.759 \\
\hline Sida cordifolia $\mathrm{L}$. & 45638 & 2900 & 0.0111 & 10 & 1.28 & 0.754 \\
\hline Amaranthaceae & & 53300 & 0.0962 & 63 & 4.28 & \\
\hline Alternanthera tenella Colla & 45397 & 53000 & 0.0946 & 60 & 11.45 & 0.788 \\
\hline Amaranthus viridis L. & 45398 & 300 & 0.0016 & 3 & 0.32 & 0.334 \\
\hline
\end{tabular}

Registry number - herbarium of Professor Vasconcelos Sobrinho/Universidade Federal Rural de Pernambuco; AD - absolute density (individuals/ha); ADo - absolute dominance $\left(\mathrm{m}^{2} / \mathrm{ha}\right)$; AF - absolute frequency (\%); IVI - importance value index; MEVI - mixed ecological value index. *families and species observed only. 
Table 1. Continued...

\begin{tabular}{|c|c|c|c|c|c|c|}
\hline Family/species & $\begin{array}{c}\text { Registry } \\
\text { number }\end{array}$ & AD & ADo & $\mathbf{A F}$ & IVI & MEVI \\
\hline Capparaceae & & 42400 & 0.0600 & 70 & 4.14 & \\
\hline Cleome diffusa Banks ex DC. & 45416 & 41900 & 0.0593 & 70 & 11.21 & 0.454 \\
\hline Cleome rotundifolia (Mart. \& Zucc.) H.H. Iltis & 45419 & 500 & 0.0007 & 3 & 0.34 & 0.334 \\
\hline Portulacaceae & & 35600 & 0.0728 & 52 & 3.23 & \\
\hline Portulaca elatior Mart. & 45839 & 27300 & 0.0268 & 41 & 6.84 & 0.272 \\
\hline Portulaca mucronata Link & 45835 & 7500 & 0.0346 & 28 & 3.52 & 0.261 \\
\hline Portulaca oleraceae L. & 45834 & 800 & 0.0113 & 6 & 0.67 & 0.252 \\
\hline Portulaca umbraticola Kunt. & 45833 & $*$ & & & & \\
\hline Lamiaceae & & 15400 & 0.0510 & 43 & 2.18 & \\
\hline Hyptis atrorubens Poit. & 45669 & 15400 & 0.0510 & 43 & 5.81 & 0.448 \\
\hline Convolvulaceae & & 13500 & 0.0449 & 40 & 2 & \\
\hline Ipomoea brasiliana (Choisy) Meisn. & 45428 & 10100 & 0.0363 & 34 & 4.38 & 0.764 \\
\hline Ipomoea rosea Choisy & 45433 & 1200 & 0.0035 & 4 & 0.52 & 0.501 \\
\hline Evolvulus frankenioide Moric. & 45425 & 1900 & 0.0044 & 3 & 0.49 & 0.751 \\
\hline Merremea aegyptia (L.) Urb. & 45821 & 300 & 0.0008 & 2 & 0.22 & 0.250 \\
\hline \multicolumn{7}{|l|}{ Convolvulaceae } \\
\hline Ipomoea aristolochiefolia $\mathrm{G}$. Don & 45429 & * & & & & \\
\hline Boraginaceae & & 14300 & 0.3015 & 17 & 1.26 & \\
\hline Heliotropium angiospermum Murr. & 45408 & 12000 & 0.0721 & 13 & 2.59 & 0.258 \\
\hline Heliotropium procumbens Mill. & 45410 & 2300 & 0.2294 & 7 & 1.18 & 0.253 \\
\hline Sapindaceae & & 6300 & 0.0090 & 19 & 0.94 & \\
\hline Cardiospermum sp. & 45451 & 6300 & 0.0090 & 19 & 2.50 & 0.758 \\
\hline Cyperaceae & & 16800 & 0.0037 & 3 & 0.72 & \\
\hline Cyperus uncinulatus Schrad ex Nees & 45837 & 16700 & 0.0425 & 2 & 2.00 & 0.340 \\
\hline Bulbostylis capillaris (L.) C. B. Clarke & 45651 & 100 & 0.0013 & 1 & 0.11 & 0.417 \\
\hline Asteraceae & & 2500 & 0.0062 & 14 & 0.62 & \\
\hline Blainvillea rhomboidea Cass. & 45404 & 1800 & 0.0040 & 8 & 0.96 & 0.336 \\
\hline Tridax procumbens $\mathrm{L}$. & 45406 & 700 & 0.0022 & 6 & 0.65 & 0.335 \\
\hline Emilia sonchifolia (L.) DC. & 45643 & $*$ & & & & \\
\hline Nyctaginaceae & & 4700 & 0.0207 & 10 & 0.55 & \\
\hline Boerhavia coccinea Mill. & 45465 & 4700 & 0.0207 & 10 & 1.48 & 0.338 \\
\hline Dioscoreaceae & & 4600 & 0.0026 & 10 & 0.54 & \\
\hline Dioscorea ovata Vell. & 45435 & 3000 & 0.0016 & 8 & 1.09 & 0.670 \\
\hline Dioscorea sp. & 45436 & 1600 & 0.0010 & 4 & 0.55 & 0.251 \\
\hline Aristolochiaceae & & 1800 & 0.0089 & 11 & 0.48 & \\
\hline Aristolochia birostris Duch. & 45401 & 1800 & 0.0089 & 11 & 1.26 & 0.754 \\
\hline Urticaceae & & 4100 & 0.0049 & 8 & 0.45 & \\
\hline Pilea hyalina Fenzl & 45675 & 4100 & 0.0049 & 8 & 1.21 & 0.254 \\
\hline Solanaceae & & 2100 & 0.0020 & 8 & 0.38 & \\
\hline Schwenkia americana var. angustifolia J.A.Schmidt in Mart. & 45823 & 1900 & 0.0009 & 8 & 0.97 & 0.586 \\
\hline Physalis neesiana Sendt. & 45449 & 200 & 0.0010 & 1 & 0.12 & 0.250 \\
\hline Amaryllidaceae & & 1100 & 0.0082 & 7 & 0.31 & \\
\hline Hippeastrum sp. & 45832 & 1100 & 0.0082 & 7 & 0.80 & 0.502 \\
\hline Moraceae & & 1500 & 0.0098 & 6 & 0.28 & \\
\hline Dorstenia sp. & 45635 & 1500 & 0.0098 & 6 & 0.75 & 0.252 \\
\hline
\end{tabular}

Registry number - herbarium of Professor Vasconcelos Sobrinho/Universidade Federal Rural de Pernambuco; AD - absolute density (individuals/ha); ADo - absolute dominance ( $\left.\mathrm{m}^{2} / \mathrm{ha}\right)$; AF - absolute frequency (\%); IVI - importance value index; MEVI - mixed ecological value index. *families and species observed only. 
Table 1. Continued...

\begin{tabular}{|c|c|c|c|c|c|c|}
\hline Family/species & $\begin{array}{l}\text { Registry } \\
\text { number }\end{array}$ & AD & ADo & $\mathbf{A F}$ & IVI & MEVI \\
\hline Tiliaceae & & 2300 & 0.0012 & 4 & 0.23 & \\
\hline Corchorus hirtus L. & 45677 & 2300 & 0.0012 & 4 & 0.63 & 0.418 \\
\hline Rhamnaceae & & 500 & 0.0002 & 3 & 0.13 & \\
\hline Crumenaria decumbens Mart. & 45453 & 500 & 0.0002 & 3 & 0.34 & 0.667 \\
\hline Fabaceae & & 200 & 0.0003 & 2 & 0.08 & \\
\hline Zornia brasiliensis Vogel & 45672 & 200 & 0.0003 & 2 & 0.21 & 0.750 \\
\hline Scrophulariaceae & & 200 & 0.0003 & 2 & 0.08 & \\
\hline Tetraulacium veronicaeforme Turcz. & 45450 & 200 & 0.0003 & 2 & 0.21 & 0.250 \\
\hline Angelonia cornigera Hook. & 45827 & $*$ & & & & \\
\hline Bignoniaceae & & $*$ & & & & \\
\hline Anemopaegma laeve DC. & 45407 & $*$ & & & & \\
\hline Asclepiadaceae & & $*$ & & & & \\
\hline Matelea maritima subsp. ganglinosa (Vell.) Fontella & 45403 & $*$ & & & & \\
\hline
\end{tabular}

Registry number - herbarium of Professor Vasconcelos Sobrinho/Universidade Federal Rural de Pernambuco; AD - absolute density (individuals/ha); ADo - absolute dominance $\left(\mathrm{m}^{2} / \mathrm{ha}\right)$; AF - absolute frequency (\%); IVI - importance value index; MEVI - mixed ecological value index. *families and species observed only.

\section{Discussion}

\subsection{Species richness and composition}

The species richness found in both the sedimentary and crystalline areas was higher than that recorded in other arid environments in the world, which ranges from 33 to 75 species (Aarrestad et al., 2011; Alhamad et al., 2010; Donovan et al., 2010; He et al., 2007; Ramírez et al. 2007), and was similar to the range (from 21 to 71 species) found in other caatinga areas (Araújo et al., 2005; Feitoza et al., 2008; Maracajá and Benevides, 2006; Reis et al., 2006). In general, both species richness and composition were similar between the sedimentary and crystalline areas (Tables 1 and 2). Despite the differences in soil characteristics, the number of species in common between areas was high. Possibly, this similarity is explained by the proximity between the areas. In other words, proximity between areas would be a factor capable of attenuating the influence that soil type would have on the composition of herbaceous plants.

\subsection{Structure}

The density recorded in the crystalline area $(952.500$ individuals/ha) is within the range $(27,680$ to $1,342,700$ individuals/ha) of that recorded for the herbaceous layers in other caatinga areas (Araújo et al. 2005; Feitoza et al., 2008; Maracajá and Benevides, 2006; Reis et al., 2006), and was even higher in the sedimentary area (1,613,300 individuals/ ha). Although the soil of the crystalline area had a higher water retention capacity and higher fertility (Silva et al., 2009), the density of the herbaceous community was significantly lower in this area than in the sedimentary area.

Because the climatic conditions of the areas were similar as a result of their proximity, the difference in density may be attributed to the less favourable rooting conditions (presence of rocky outcrops) in the crystalline area. Another factor that may contribute to the lower herb density in the crystalline area is the weaker light penetration through the closed canopy. According to Araújo-Filho et al. (2002) and Silva et al. (2009, 2010), shade impairs the establishment of some herbaceous caatinga species, reducing the sizes of their populations, although in other dry forests around the world, the shade produced by woody plants provides favourable conditions for the maintenance of herbaceous plants, enabling them to access more moisture- and nutrient-rich soils beneath the crowns of trees (Fuller, 1999).

The higher fertility, particularly the higher amount of phosphorus $(\mathrm{P})$ and the greater water retention capacity, of the soil in the crystalline area (Silva et al., 2009) may explain the variations in the vertical and horizontal organization of the herbaceous communities because the average height $(25.32 \pm 39.02)$ and diameter $(1.16 \pm 2.56)$ of the herbs in the more fertile soils of the crystalline area were significantly larger than the average height $(4.86 \pm 2.02)$ and diameter $(0.14 \pm 0.17)$ of herbs in the sedimentary area.

Only the total basal area of plants in the sedimentary area $\left(28.16 \mathrm{~m}^{2} / \mathrm{ha}\right)$ is within the range recorded $(0.28$ to $73.26 \mathrm{~m}^{2} / \mathrm{ha}$ ) in other studies of the herbaceous component of the caatinga (Feitoza et al., 2008; Reis et al., 2006). The high basal area of species in the crystalline area $\left(85.86 \mathrm{~m}^{2} / \mathrm{ha}\right)$ may be explained by the presence of Cactaceae and Bromeliaceae species with high individual basal area and population density. Prior to this study, the high basal area $\left(73.26 \mathrm{~m}^{2} / \mathrm{ha}\right)$ recorded by Feitoza et al. (2008) was also attributed to the high occurrence of Cactaceae and Bromeliaceae. The species responsible for the high basal area in the crystalline area were Encholirium spectabile, 
Table 2. Phytosociological characterisation of a caatinga herbaceous community in a sedimentary area, Petrolândia, Pernambuco, Brazil, with families ranked by decreasing values of the importance value index.

\begin{tabular}{|c|c|c|c|c|c|c|}
\hline Family/species & $\begin{array}{l}\text { Registry } \\
\text { number }\end{array}$ & AD & ADo & $\mathbf{A F}$ & IVI & MEVI \\
\hline Cactaceae & & 12000 & 25.1223 & 14 & 30.43 & \\
\hline Opuntia inamoena K. Schum. & 45818 & 12000 & 25.1223 & 14 & 90.94 & 1.303 \\
\hline Rubiaceae & & 425700 & 0.1165 & 98 & 12.06 & \\
\hline Staelia virgata (L. \& S.) K.Schum. & 45845 & 229000 & 0.0271 & 88 & 20.48 & 0.651 \\
\hline Richardia grandiflora (Cham.\& Schltdl.) Steud. & 45847 & 196700 & 0.0894 & 86 & 18.56 & 0.728 \\
\hline Convolvulaceae & & 190200 & 0.4111 & 91 & 7.83 & \\
\hline Evolvulus frankenioides Moric. & 45424 & 162900 & 0.2386 & 72 & 16.01 & 0.803 \\
\hline Ipomoea brasiliana (Choisy) Meisn. & 45427 & 26300 & 0.1717 & 52 & 5.90 & 0.686 \\
\hline Ipomoea rosea Choisy & 45426 & 800 & 0.0002 & 3 & 0.26 & 0.584 \\
\hline Merremia aegyptia (L.) Urb. & 45432 & 200 & 0.0006 & 1 & 0.08 & 0.500 \\
\hline Poaceae & & 150200 & 0.1326 & 94 & 6.26 & \\
\hline Panicum trichoides $\mathrm{Sw}$. & 45657 & 72000 & 0.0294 & 49 & 8.01 & 0.360 \\
\hline Eragrostis ciliaris (L.) R. Br. & 45458 & 32800 & 0.0504 & 45 & 5.38 & 0.767 \\
\hline Axonopus capillaris (Lam.) Chase & 45648 & 14700 & 0.0235 & 39 & 3.74 & 0.595 \\
\hline Dactyloctenium aegyptium (L.) K.Richt & 45663 & 10700 & 0.0121 & 19 & 2.04 & 0.506 \\
\hline Eragrostis acutiflora (H. B. K.) Nees & 45656 & 15200 & 0.0108 & 11 & 1.75 & 0.672 \\
\hline \multicolumn{7}{|l|}{ Poaceae } \\
\hline Eragrostis pilosa (L.) P. Beauv. & 45828 & 2600 & 0.0013 & 9 & 0.80 & 0.336 \\
\hline Tragus berteronianus Schult. & 45455 & 2200 & 0.0052 & 8 & 0.72 & 0.502 \\
\hline Digitaria sanguinalis (L.) Scop. & 45652 & $*$ & & & & \\
\hline Enteropogum mollis (Nees) Clayton & 45659 & $*$ & & & & \\
\hline Eragrostis amabilis (L.) Wight \& Arn. & 45654 & $*$ & & & & \\
\hline Molluginaceae & & 172700 & 0.2306 & 75 & 6.23 & \\
\hline Mollugo verticillata $\mathrm{L}$. & 45636 & 172700 & 0.2306 & 75 & 16.80 & 0.472 \\
\hline Portulacaceae & & 142600 & 0.1442 & 82 & 5.73 & \\
\hline Portulaca elatior Mart. & 45830 & 98300 & 0.0804 & 69 & 11.23 & 0.370 \\
\hline Portulaca mucronata Link. & 45831 & 43700 & 0.0596 & 62 & 7.28 & 0.357 \\
\hline Portulaca oleraceae L. & 45829 & 600 & 0.0042 & 3 & 0.26 & 0.250 \\
\hline Lamiaceae & & 104000 & 0.1350 & 93 & 5.28 & \\
\hline Hyptis atrorubens Poit. & 45836 & 95000 & 0.1333 & 93 & 12.90 & 0.793 \\
\hline Hypenia salzmannii (Benth) Harley & 45670 & 9000 & 0.0017 & 30 & 2.67 & 0.675 \\
\hline Euphorbiaceae & & 140900 & 0.0202 & 70 & 5.17 & \\
\hline Phyllanthus niruri L. & 45447 & 124900 & 0.0120 & 66 & 12.43 & 0.458 \\
\hline Bernardia sidoides (Klotzsch) Müll. Arg. & 45439 & 5700 & 0.0031 & 20 & 1.77 & 0.505 \\
\hline Acalypha poiretii Spreng. & 45437 & 7100 & 0.0036 & 7 & 0.95 & 0.419 \\
\hline Chamaesyce hyssopifolia (L.) Small & 45840 & 2300 & 0.0003 & 10 & 0.85 & 0.669 \\
\hline Microstachys corniculata (Vahl.) Griseb. & 45841 & 500 & 0.0011 & 3 & 0.25 & 0.417 \\
\hline Croton lobatus (L.) Müll. Arg. & 45442 & 400 & 0.0001 & 3 & 0.24 & 0.334 \\
\hline Croton glandulosus L. & 45649 & $*$ & & & & \\
\hline \multicolumn{7}{|l|}{ Euphorbiaceae } \\
\hline Phyllanthus heteradenius Müll. Arg. & 45446 & $*$ & & & & \\
\hline Amaranthaceae & & 120800 & 0.0991 & 57 & 4.43 & \\
\hline Alternanthera tenella Colla & 45396 & 119500 & 0.0973 & 56 & 11.69 & 0.788 \\
\hline Amaranthus viridis L. & 45399 & 1300 & 0.0017 & 4 & 0.37 & 0.417 \\
\hline
\end{tabular}

Registry number - herbarium of Professor Vasconcelos Sobrinho/Universidade Federal Rural de Pernambuco; AD - absolute density (individuals/ha); ADo - absolute dominance $\left(\mathrm{m}^{2} / \mathrm{ha}\right)$; AF - absolute frequency $(\%)$; IVI - importance value index; MEVI - mixed ecological value index; *families and species observed only. 
Table 2. Continued...

\begin{tabular}{|c|c|c|c|c|c|c|}
\hline Family/species & $\begin{array}{l}\text { Registry } \\
\text { number }\end{array}$ & AD & ADo & $\mathbf{A F}$ & IVI & MEVI \\
\hline Amaryllidaceae & & 9100 & 1.3932 & 39 & 3.08 & \\
\hline Amaryllidaceae 01 & 45650 & 4000 & 1.3668 & 5 & 5.45 & 0.684 \\
\hline Hippeastrum sp. & 45400 & 5100 & 0.0264 & 36 & 2.94 & 0.426 \\
\hline Capparaceae & & 29900 & 0.0290 & 66 & 2.76 & \\
\hline Cleome rotundifolia (Mart.\& Zucc.) H.H. Iltis & 45418 & 18800 & 0.0204 & 55 & 5.11 & 0.600 \\
\hline Cleome diffusa Banks ex DC. & 45415 & 6400 & 0.0061 & 18 & 1.68 & 0.672 \\
\hline Cleome guianensis Aubl. & 45417 & 13300 & 0.0015 & 7 & 0.70 & 0.419 \\
\hline Dactylaena micrantha Schrad. ex Schult.f. & 45420 & 1400 & 0.0010 & 6 & 0.51 & 0.668 \\
\hline Malvaceae & & 24600 & 0.0152 & 60 & 2.44 & \\
\hline $\begin{array}{l}\text { Pseudomalacra guianensis (K. Schum.) H. } \\
\text { Monteiro }\end{array}$ & 45664 & 14300 & 0.0027 & 46 & 4.13 & 0.763 \\
\hline Herissantia tiubae (K. Schum.) Brizicky & 45667 & 8700 & 0.0122 & 23 & 2.20 & 0.840 \\
\hline Sida cordifolia $\mathrm{L}$. & 45662 & 1600 & 0.0004 & 9 & 0.73 & 0.752 \\
\hline Herissantia crispa (L.) Brizicky & 45668 & $*$ & & & & \\
\hline Cyperaceae & & 39600 & 0.1422 & 31 & 1.98 & \\
\hline Bulbostylis capillaris (L.) C.B.Clark & 45430 & 16300 & 0.0977 & 19 & 2.69 & 0.675 \\
\hline Cyperus laxus Lam. & 45434 & 22000 & 0.0439 & 15 & 2.57 & 0.591 \\
\hline Pycreus propinquus Nees & 45660 & 1300 & 0.0006 & 5 & 0.43 & 0.334 \\
\hline \multicolumn{7}{|l|}{ Cyperaceae } \\
\hline Cyperus uncinulatus Schrad ex Nees & 45661 & $*$ & & & & \\
\hline Commelinaceae & & 11900 & 0.0946 & 40 & 1.63 & \\
\hline Commelina obliqua $\mathrm{Vahl}$ & 45653 & 10100 & 0.0941 & 38 & 3.63 & 0.678 \\
\hline Callisia repens $\mathrm{L}$. & 45422 & 1800 & 0.0005 & 5 & 0.46 & 0.251 \\
\hline Fabaceae & & 5500 & 0.0045 & 31 & 1.11 & \\
\hline Zornia brasiliensis Vogel & 45673 & 4200 & 0.0018 & 24 & 1.95 & 0.756 \\
\hline Zornia gemella (Willd.) Vogel & 45671 & 1300 & 0.0026 & 10 & 0.79 & 0.752 \\
\hline Crotalaria incana $\mathrm{L}$. & 45639 & $*$ & & & & \\
\hline Aeschynomene viscidula Michx. & 45640 & $*$ & & & & \\
\hline Sapindaceae & & 5200 & 0.0020 & 16 & 0.62 & \\
\hline Cardiospermum sp. & 45452 & 5200 & 0.0020 & 16 & 1.45 & 0.754 \\
\hline Nyctaginaceae & & 5700 & 0.0155 & 15 & 0.61 & \\
\hline Boerhavia coccinea Mill. & 45464 & 5700 & 0.0155 & 15 & 1.46 & 0.421 \\
\hline Sterculiaceae & & 4500 & 0.0022 & 13 & 0.51 & \\
\hline Ayenia erecta Mart. & 45448 & 4200 & 0.0022 & 10 & 0.97 & 0.753 \\
\hline Waltheria rotundifolia $\mathrm{K}$. Schum. & 45838 & 300 & - & 3 & 0.23 & 0.667 \\
\hline Waltheria macropoda Turcz. & 45647 & $*$ & & & & \\
\hline Tiliaceae & & 3200 & 0.0014 & 12 & 0.45 & \\
\hline Corchorus hirtus L. & 45678 & 3200 & 0.0014 & 12 & 1.05 & 0.253 \\
\hline Scrophulariaceae & & 4500 & 0.0009 & 11 & 0.44 & \\
\hline Tetraulacium veronicaeforme Turcz. & 45450 & 4500 & 0.0009 & 11 & 1.06 & 0.336 \\
\hline Angelonia cornigera Hook. & 45822 & $*$ & & & & \\
\hline Aristolochiaceae & & 2600 & 0.0349 & 9 & 0.38 & \\
\hline Aristolochia birostris Duch. & 45402 & 2600 & 0.0349 & 9 & 0.92 & 0.753 \\
\hline Asteraceae & & 2200 & 0.0024 & 7 & 0.27 & \\
\hline Blainvillea rhomboidea Cass. & 45405 & 12200 & 0.0024 & 7 & 0.64 & 0.252 \\
\hline
\end{tabular}

Registry number - herbarium of Professor Vasconcelos Sobrinho/Universidade Federal Rural de Pernambuco; AD - absolute density (individuals/ha); ADo - absolute dominance ( $\left.\mathrm{m}^{2} / \mathrm{ha}\right)$; AF - absolute frequency (\%); IVI - importance value index; MEVI - mixed ecological value index; *families and species observed only. 
Table 2. Continued...

\begin{tabular}{|c|c|c|c|c|c|c|}
\hline Family/species & $\begin{array}{l}\text { Registry } \\
\text { number }\end{array}$ & AD & ADo & $\mathbf{A F}$ & IVI & MEVI \\
\hline Acanthospermum hispidum DC. & 45820 & $*$ & & & & \\
\hline Centratherum punctatum Cass. & 45824 & $*$ & & & & \\
\hline Emilia sonchifolia (L.) DC. & 45825 & $*$ & & & & \\
\hline Tridax procumbens $\mathrm{L}$. & 45658 & $*$ & & & & \\
\hline Dioscoreacea & & 900 & 0.0010 & 7 & 0.24 & \\
\hline Dioscorea ovata Vell. & 45642 & 500 & 0.0004 & 5 & 0.38 & 0.667 \\
\hline Dioscorea sp. & 45436 & 400 & 0.0006 & 2 & 0.17 & 0.333 \\
\hline Caesalpiniaceae & & 1800 & 0.0008 & 6 & 0.23 & \\
\hline Chamaecrista trichopoda (Benth.) Briton \& Killip. & 45655 & 1800 & 0.0008 & 6 & 0.54 & 0.751 \\
\hline Phytolacaceae & & 1300 & 0.0014 & 4 & 0.16 & \\
\hline Microtea paniculata Moq. & 45462 & 1300 & 0.0014 & 4 & 0.37 & 0.251 \\
\hline Boraginaceae & & 1500 & 0.0075 & 2 & 0.1 & \\
\hline Heliotropium angiospermum Murr. & 45409 & 1500 & 0.0075 & 2 & 0.26 & 0.667 \\
\hline Turneraceae & & 100 & 0.0013 & 1 & 0.04 & \\
\hline Turnera ulmifolia $\mathrm{L}$. & 45676 & 100 & 0.0013 & 1 & 0.08 & 0.333 \\
\hline Curcubitaceae & & 100 & 0.0002 & 1 & 0.03 & \\
\hline Ceratosanthes trifoliata Cogn. & 45431 & 100 & 0.0002 & 1 & 0.08 & 0.250 \\
\hline Iridaceae & & $*$ & & & & \\
\hline Cipura paludosa Aubl. & 45819 & $*$ & & & & \\
\hline Papaveraceae & & $*$ & & & & \\
\hline Argemone mexicana $\mathrm{L}$. & 45826 & $*$ & & & & \\
\hline Passifloraceae & & $*$ & & & & \\
\hline Passiflora foetida $\mathrm{L}$. & 45463 & $*$ & & & & \\
\hline Verbenaceae & & $*$ & & & & \\
\hline Stachytarpheta sanguinea Mart. ex Schau & 45674 & $*$ & & & & \\
\hline
\end{tabular}

Registry number - herbarium of Professor Vasconcelos Sobrinho/Universidade Federal Rural de Pernambuco; AD - absolute density (individuals/ha); ADo - absolute dominance ( $\left.\mathrm{m}^{2} / \mathrm{ha}\right)$; AF - absolute frequency (\%); IVI - importance value index; MEVI - mixed ecological value index; *families and species observed only.

Hohenbergia catingae, Neoglaziovia variegata, Opuntia inamoena and Melocactus bahiensis (Table 1), whereas in the sedimentary area they were Opuntia inamoena and unidentified species of Amaryllidaceae (Table 2). The removal of these species from sampling would reduce the total basal area of the crystalline area to $2.01 \mathrm{~m}^{2} / \mathrm{ha}$ and that of the sedimentary area to $3.03 \mathrm{~m}^{2} / \mathrm{ha}$, where these values are similar to those recorded for the herbaceous component, of which most species have thin stalks.

Studies conducted in different regions with arid and semiarid environments around the world have shown that variations in plant establishment conditions, such as variations in soil physicochemical characteristics, may cause changes in herbaceous community structure (Aarrestad et al., 2011; Alhamad et al., 2010; He et al., 2007; Morgenthal et al., 2006; Ramírez et al., 2007). In this study, the significant differences recorded between the average values for density, diameter and height show that the herbaceous community in the crystalline area is dominated by a few individuals with thicker stalks and a higher canopy. In contrast, the herbaceous community in the sedimentary area is characterised by the presence of almost twice as many individuals as in the crystalline area, but the individuals have thinner stalks and a shorter canopy. This study demonstrates that variations in plant establishment conditions between crystalline and sedimentary caatinga areas are a modelling factor for the structure of herbaceous communities.

Of the families with a high IVI, only Bromeliaceae, Cactaceae, Convolvulaceae and Molluginaceae had already been reported to have high IVIs in other caatinga areas (Feitoza et al., 2008; Reis et al., 2006). Variations in microhabitats led to different families having higher importance; only Cactaceae was found on the list of the five families with the highest IVI in both areas (Tables 1 and 2).

At the population level, in the crystalline area, the high IVI values of Callisia repens and Microtea paniculata resulted from their high density and frequency, characterising them as abundant species with relatively even distribution. For Encholirium spectabile, Hohenbergia catingae and 


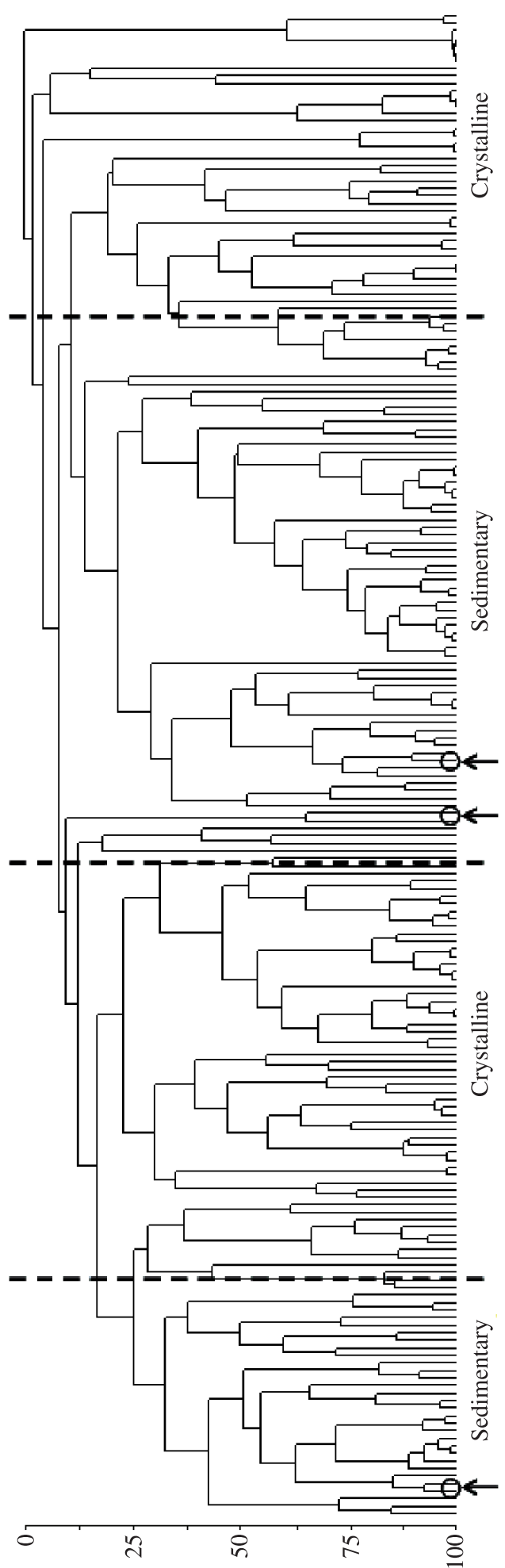

Figure 1. Structural similarity between the sedimentary and crystalline areas of a caatinga area in the semi-arid climate of northeastern Brazil. Arrows indicate the position of plots from the crystalline area that were grouped with plots from the sedimentary area. Limit of reliability of connections Sorensen index $=0,77 ; \alpha=0.05 \%$; Number of permutations $=200$.
Opuntia inamoena, the high IVI values were the result of the dominance parameter, indicating that these species influenced the physiognomy of the crystalline area because of the higher basal area arising from the diameter of their stalks or rosettes (Table 1). Of the species not possessing the highest IVI values, Mollugo verticilata, Panicum tricoides, Phyllanthus niruri, Alternanthera tenella and Cleome diffusa were important in the community because of their high density and/or frequency, indicating that these species are numerous and have a more even spatial distribution in the crystalline area (Table 1).

The calculation of the MEVI showed that in the crystalline area, the species with the highest mixed ecological importance were not necessarily those with the highest IVI values (Table 1). Of the 10 species with high IVI in this study, only E. spectabile, $H$. catingae, O. inamoena and A. tenella also had high MEVI values. The lower values in the other species can be explained by the death of the aboveground parts of most of their individuals provoked by the onset of the dry season, which precludes their involvement in the maintenance of the local fauna throughout the climatic seasons. The species that occupied their places were Melocactus bahiensis, Neoglaziovia variegata, Herissantia tiubae, Ipomoea brasiliana, Pseudomalacra guianensis and Cardiospermum sp. (Table 1).

The high values for MEVI in Bromeliaceae and Cactaceae species is consistent with the trend reported by Feitoza et al. (2008), as these families are perennial and remain visible in the environment all year long. However, the species with high MEVI in the area studied by Feitoza et al. (2008) were not the same as those identified in this study, which shows that there are differences between the caatinga areas in the timing and diversity of vegetation resource availability for fauna in semiarid environments.

In the sedimentary area, the IVI value of Opuntia inamoena was greatly influenced by the large diameters of individual plants. For Staelia virgata, Richardia grandiflora, Mollugo verticilata and Evolvulus frankenioides, the IVI values were determined by the degree of relative density and/ or frequency. In addition to these species, Hyptis atrorubens, Phyllanthus niruri, Alternanthera tenella, Portulaca elatior and Panicum trichoides were also prominent as a result of their high density and/or frequency, although they were not among the five species with the highest IVI (Table 2).

Although Staelia virgata, Richardia grandiflora, Mollugo verticilata, Phyllanthus niruri, Portulaca elatior and Panicum trichoides had high IVI values in the sedimentary area, they had relatively lower values for MEVI (Table 2). This decrease may be explained by the death of this group of species with the onset of the dry season. The species that replaced them included Herissantia tiubae, Eragrostis ciliaris, Pseudomalacra guianensis, Zornia brasiliensis, Cardiospermum sp. and Ayenia erecta, all of which are more resistant to drought (Table 2).

In periods of short summer droughts within the rainy season, most of the therophytic herbaceous species would lose their leaves and appear to be dead. The therophytes most sensitive to variations in the microclimate could 
not survive and would complete their life cycle in just two or three months. Another group of therophytes was more resistant to variations in microclimate. In this group, the individuals replaced lost leaves following the end of the period of hydric stress (short summer drought); they even flourished and bore fruit. In the crystalline area, species belonging to this group of plants included Alternanthera tenella, Cleome diffusa, Enteropogon mollis, Eragrastis ciliaris, Herissantia tiubae, Hyptis atrorubens and Pseudomalacra guianensis; in the sedimentary area, these were Hyptis atrorubens, Alternanthera tenella, Pseudomalacra guianensis, Zornia brasiliensis, Richardia grandiflora, Staelia virgata and Cleome rotundifolia. This strategy of adjusting to hydric stress in the middle of the rainy season was previously recorded for other herbaceous species in a more humid caatinga area (Araújo et al., 2005; Lima et al., 2007; Silva et al., 2008).

The species in this study with the highest density differed from those in other caatinga areas (Araújo et al., 2005; Feitoza et al., 2008; Reis et al., 2006). Of the high-density species, only Mollugo verticilata, Panicum trichoides, Phyllanthus niruri and Richardia grandiflora were common to crystalline and sedimentary areas, which shows that variations in plant establishment conditions, in both crystalline and sedimentary caatinga areas, may cause changes in the structure of herbaceous populations.

In general, the values obtained for the Shannon-Weiner diversity index in the crystalline (2.96 nats/ind.) and sedimentary (2.89 nats/ind.) areas were similar. These values were high in comparison with those obtained by Araújo et al. (2005) and Feitoza et al. (2008), which ranged from 0.82 to 2.53 nats/ind., and were below the value recorded by Reis et al. (2006), which was 3.01 nats/ind. ${ }^{-1}$. The evenness values found in the present study were also similar between the crystalline (0.72) and sedimentary $(0.71)$ areas. These values are similar to those recorded by Reis et al. (2006), which were 0.71 and 0.77 . According to these authors, the high equability indicates a close similarity in herbaceous species' ability to utilize the resources in the environment during the short rainy season in comparison to woody species. On the other hand, the evenness values of the present study were relatively high compared to that recorded by Feitoza et al. (2008), which was 0.28; however, it is important to note that the period considered in this study was extremely dry and therefore atypical for the region. This finding shows that the distribution of the number of individuals by species for the herbaceous component is quite variable among caatinga areas and may be directly related to total rainfall; there is a need for further study to obtain a clearer understanding of this variation.

Results of the group analysis showed that the groups in plots of the crystalline area were more pure than the groups formed by sedimentary area plots; five plots of the crystalline area were mixed with groups from the sedimentary area, whereas no plot in the sedimentary area was grouped with plots in the crystalline area (Figure 1). The structural differences found between the two areas may reflect the spatial micro-variations of plant establishment conditions; in both areas, although they were not measured, differences were observed in the shade conditions created by the tree canopies and rocky outcrops and the presence of leaf litter (see Silva et al., 2009).

This study demonstrates that the soils of sedimentary and crystalline areas cause changes in the organization of herbaceous communities in the caatinga. It also shows that in the herbaceous community there are differences between the types of drought-sensitive herbs; furthermore, there is a group of species that is visible throughout the year and a group that is visible for only part of the year.

Acknowledgements - The authors thank the experts Afrânio Fernandes, Alexa Araújo, Ana Paula Fortuna Peres, André Laurênio de Melo, Iranildo Melo, Ângela Maria Miranda, Elnatan Bezerra, Jéferson Rodrigues, Josafá Siqueira, José Alves Siqueira, Marcos J. Silva, Maria Bernadete Costa e Silva, Maria de Fátima A. Lucena, Rita Pereira, Roxana Pereira and Suzene Izidio da Silva, who helped with plant identification; the Programa de Pós-Graduação em Botânica da Universidade Federal Rural de Pernambuco; CNPq for granting scholarship support and, especially, Mrs. Maria Elita Ramalho Leal and all her family for receiving us as guests in their home during field research.

\section{References}

AARRESTAD, PA., MASUNGA, GS., HYTTEBORN, H., PITLAGANO, ML., MAROKANE, W. and SKARPE, C., 2011. Influence of soil, tree cover and large herbivores on field layer vegetation along a savanna landscape gradient in northern Botswana. Journal of Arid Environments, vol. 75, p. 290-297. http://dx.doi. org/10.1016/j.jaridenv.2010.10.009

ALBUQUERQUE, UP., ANDRADE, LHC. and CABALLERO, J., 2005. Structure and floristics of homegardens in Northeastern Brazil. Journal of Arid Environments, vol. 62, p. 491-506. http:// dx.doi.org/10.1016/j.jaridenv.2005.01.003

ALCOFORADO-FILHO, FG., SAMPAIO, EVSB. and RODAL, MJN., 2003. Florística e fitossociologia de um remanescente de vegetação caducifólia espinhosa arbórea em Caruaru, Pernambuco. Acta Botanica Brasílica, vol. 17, p. 287-303.

ALHAMAD, MN., OSWALD, BP., BATAINEH, MM., ALRABABAH, MA. and Al-GHARAIBEH, MM., 2010. Relationships between herbaceous diversity and biomass in two habitats in arid Mediterranean rangeland. Journal of Arid Environments, vol. 74, p. 277-283. http://dx.doi.org/10.1016/j. jaridenv.2009.08.009

ANDRADE-LIMA, D., 1981. The caatingas dominun. Revista Brasileira de Botânica, vol. 4, p. 149-163.

AMORIM, PK. and BATALHA, MA., 2008. Soil chemical factors and grassland species density in Emas National Park (central Brazil). Brazilian Journal of Biology, vol. 68, no. 2, p. 279-285. PMid:18660955. http://dx.doi.org/10.1590/S151969842008000200008

ARAÚJO FILHO, JA., CARVALHO, FC., GARCIA, R. and SOUSA, RA., 2002. Efeitos da manipulação da vegetação lenhosa sobre a produção e compartimentalização da fitomassa pastável de uma caatinga sucessional. Revista Brasileira de Zootecnia, vol. 31, p. 11-19. http://dx.doi.org/10.1590/S1516-35982002000100002 
ARAÚJO, EL., CASTRO, CC. and ALBUQUERQUE, UP., 2007. Dynamics of Brazilian Caatinga - A Review Concerning the Plants, Environment and People. Functional ecology and communities, vol. 1, p. 15-28.

ARAÚJO, EL., SILVA, SI. and FERRAZ, EMN., 2002. Herbáceas da caatinga de Pernambuco. In SILVA, J.M., TABARELLI, M. (Eds.). Diagnóstico da biodiversidade do estado de Pernambuco. Recife: Sectma, p. 183-206.

ARAÚJO, EL., SILVA, KA., FERRAZ, EMN., SAMPAIO, EVSB. and SILVA, SI., 2005. Diversidade de herbáceas em microhabitats rochoso, plano e ciliar em uma área de caatinga, Caruaru-PE. Acta Botanica Brasílica, vol. 19, p. 285-294. http://dx.doi.org/10.1590/ S0102-33062005000200011

ARAÚJO, FS., MARTINS, FR. and SHEPHERD, GJ., 1999. Variações estruturais e florísticas co carrasco no planalto da Ibiapaba, estado do Ceará. Revista Brasileira de Biologia = Brazilian Journal of Biology, vol. 59, no. 4, p. 663-678.

Brasil. Ministério das Minas e Energia. Projeto RADAMBRASIL, 1983. Geologia, geomorfologia, pedologia, vegetação e uso potencial da terra. Rio de Janeiro: Ministério da Minas e Energia. (Levantamento de Recursos Naturais, 30)

BRUMMITT, RK. and POWELL, CE., 1992. Authors of Plant Names. Royal Botanical Garden, Kew.

CABIN, RJ. and MARSHALL, DL., 2000. The demographic role of soil seed banks I: Spatial and temporal comparisons of below and above-ground populations of the desert mustard Lesquerella fendleri. Journal of Ecology, vol. 88, p. 283-292. http://dx.doi. org/10.1046/j.1365-2745.2000.00443.x

CAÑADAS, EM., JIMÉNEZ, MN., VALLE, F., FERNÁNDEZONDOÑO, E., MARTÍN-PEINADO, F. and NAVARRO, FB., 2010. Soil-vegetation relationships in semi-arid Mediterranean old fields (SE Spain): Implications for management. Journal of Arid Environments, vol. 74, p. 1525-1533. http://dx.doi.org/10.1016/j. jaridenv.2010.06.007

CRONQUIST, A., 1988. An integrated system of classification of flowering plants. New York: Columbia University Press. PMid:3285657.

DONOVAN, JC., JILL, EC., SCOTT, RA. and CHERYL, HV., 2010. Factors affecting exotic annual plant cover and richness along roadsides in theeastern Mojave Desert, USA. Journal of Arid Environments, vol. 74, p. 702-707. http://dx.doi.org/10.1016/j. jaridenv.2009.10.012

FEITOZA, MOM., ARAÚJO, EL., SAMPAIO, EVSB., KIILL, LHP., 2008. Fitossociologia e danos foliares ocorrentes na comunidade herbácea de uma área de caatinga em Petrolina, PE. In ALBUQUERQUE, UP., MOURA, AN. and ARAÚJO, EL. (EDS.). Biodiversidade, potencial econômico e processos eco-fisiologicos em ecossistemas nordestinos. Recife: Comunigra/Nupea. p. 6-3.

Fundação de Desenvolvimento Municipal do Interior de Pernambuco - FIAM/DI, 1986. Enciclopédia dos municípios do interior de Pernambuco. Recife: FIAM/DI.

FULBRIGHT, TE., 2004. Disturbance effects on species richness of herbaceous plants in a semi-arid habitat. Journal of Arid Environments, vol. 58, p. 119-133. http://dx.doi.org/10.1016/ S0140-1963(03)00132-0
FULLER, DO., 1999. Canopy phenology of some mopane and miombo woodlands in eastern Zambia. Global Ecology and Biogeography, vol. 8, p. 199-209. http://dx.doi.org/10.1046/j.13652699.1999.00130.x

HE, MZ., ZHENG, JG., Li, XR. and QIAN, YL., 2007. Environmental factors affecting vegetation composition in the Alxa Plateau, China. Journal of Arid Environments, vol. 69, p. 473-489. http:// dx.doi.org/10.1016/j.jaridenv.2006.10.005

JACOMINE, PKT., CAVALCANTI, AC., BURGOS, N., PESSOA, SCP. and SILVEIRA, CO., 1973. Levantamento exploratório - reconhecimento de solos do Estado de Pernambuco: descrição de perfis de solos e análises. SUDENE, Recife.

LEMOS, JR. and RODAL, MJN., 2002. Fitossociologia do componente lenhoso em um trecho de vegetação de caatinga no Parque Nacional Serra da Capivara, Piauí, Brasil. Acta Botanica Brasílica, vol. 16, p. 23-42.

LIMA, EN., ARAÚJO, EL., FERRAZ, EMNR., SAMPAIO, EVSB., SILVA, KA. and PIMENTEL, RMM., 2007. Fenologia e dinâmica de duas populações herbáceas da caatinga. Revista de Geografia, vol. 24, p. 121-138.

MARACAJÁ, PB. and BENEVIDES, DS., 2006. Estudo da Flora Herbácea da Caatinga no Município de Caraúbas no Estado do Rio Grande do Norte. Revista de Biologia e Ciências da Terra, vol. 24, p. 165-175.

McCUNE, B. and MEFFORD, MJ., 1999. Pc-ord. Multivariate analysis of ecological data. version 4.0. Gleneden: MJM Software Gleneden.

MORGENTHAL, TL., KELLNER, K., VAN RENSBURG, L., NEWBY, TS. and VAN DER MERWE, J.P.A., 2006. Vegetation and habitat types of the Umkhanyakude Node. South African Journal of Botany, vol. 72, p. 1-10. http://dx.doi.org/10.1016/j. sajb.2005.03.003

MORI, SA., SILVA, LAM. and LISBOA, G., 1989. Manual de manejo do herbário fanerogâmico. Ilhéus: Centro de pesquisa do cacau.

MUNHOZ, CBR., FELFILI, JM. and RODRIGUES, C., 2008. Species-environment relationship in the herb-subshrub layer of a moist Savanna site, Federal District, Brazil. Brazilian Journal of Biology, vol. 68, no. 1, p. 25-35. PMid:18470375. http://dx.doi. org/10.1590/S1519-69842008000100005

PERAZZO, GM., 2002. Perfil do zoneamento ambiental em 29 municípios da área de Xingó. Recife: Imprensa Universitária.

RAMÍREZ, N., DEZZEO, N. and CHACÓN, N., 2007. Floristic composition, plant species abundance, and soil properties of montane savannas in the Gran Sabana, Venezuela. Flora, vol. 202, p. 306-317. http://dx.doi.org/10.1016/j.flora.2006.07.005

REIS, AMS., ARAÚJO, EL., FERRAZ, EMN. and MOURA, AN., 2006. Inter-annual variations in the floristic and population structure of an herbaceous community of "caatinga" vegetation in Pernambuco, Brazil. Acta Botânica Brasílica, vol. 29, p. 497-508.

RODAL, MJN. and NASCIMENTO, LM., 2006. The arboreal component of a dry forest in Northeastern Brazil. Brazilian Journal of Biology, vol. 66, no. 2, p. 479-491. PMid:16862303. http:// dx.doi.org/10.1590/S1519-69842006000300014 
SAMPAIO, EVSB., 1995. Overview of the Brazilian caatinga. In BULLOCK, S., MOONEY, HA. and MEDINA, E. (Eds.). Seasonally dry Tropical Forests. Cambridge: University Press. p. 35-58.

SAMPAIO, EVSB. and GAMARRA-ROJAS, CFL., 2003. A vegetação lenhosa das ecorregiões da caatinga. In JARDIM, EAG., BASTOS, MNC. and SANTOS, JUM. (Eds.). Desafios da Botânica brasileira no novo milênio: Inventário, sistematização e conservação da diversidade vegetal. Belém: Sociedade Brasileira de Botânica. p. 85-90.

SHEPHERD, GJ., 1995. Fitopac 1: Manual do Usuário. Campinas: Universidade de Campinas, Departamento de Botânica.
SILVA, KA, ARAÚJO, EL. and FERRAZ, EMN., 2009. Estudo florístico do componente herbáceo e relação com solos em áreas de caatinga do embasamento cristalino e bacia sedimentar, Petrolândia-PE. Acta Botânica Brasília, vol. 23, p. 100-110. http://dx.doi.org/10.1590/S0102-33062009000100013

SILVA, KA., ARAÚJO, EL., ALBUQUERQUE, PA. and FERRAZ, EMN., 2010. Fatores bióticos e ambientais que afetam a dinâmica de populações herbáceas em diversos tipos vegetacionais do mundo e na caatinga. In ALBUQUERQUE, UP., MOURA, AN., ARAÚJO, EL. (Eds.). Biodiversidade, Potêncial Econômico e Processos Ecológicos em Ecossistemas Nordestinos. Recife, Bauru: Canal 6. p. 65-95.

ZAR, JH., 1996. Bioestatistical Analysis. New Jersey: Prentice Hall. 